\title{
Chapter 16 \\ The Impact of Invasive Alien Plants on Rangelands in South Africa
}

\author{
Timothy G. O'Connor (D) and Brian W. van Wilgen
}

\begin{abstract}
Rangeland covers $>70 \%$ of the land surface of South Africa, and includes grassland, savanna, thicket, and karroid shrubland vegetation. These rangelands support domestic livestock and wildlife whose economic value is around ZAR 30 billion annually. They are invaded by hundreds of alien plant species, of which 71 have been identified as being of special importance in South African rangelands. These species are able to proliferate in response to disturbances, of which grazing and fire are the two most important for South African rangelands; changes to fire and grazing regimes can therefore promote invasion, especially by alien trees. These trees replace palatable grasses and are generally unpalatable themselves. At a national scale, invasive alien plants are estimated to reduce the value of livestock production by ZAR 340 million annually, but this is expected to increase dramatically as plant invasions spread, and as additional alien species become invasive. Invasive species that have increased their range dramatically by up to $671 \%$ between 2006 and 2016 include Campuloclinium macrocephalum (Pompom Weed), Opuntia engelmannii (Small Round-leaved Prickly Pear), Opuntia humifusa (Large-Flowered Prickly Pear), Parthenium hysterophorus (Parthenium Weed), Trichocereus spachianus (Torch Cactus), and Verbena bonariensis (Wild Verbena). Studies that document the impacts of individual species on rangeland composition and structure cover only a few species, including Prosopis species (Mesquite), Acacia mearnsii (Black Wattle) and Parthenium hysterophorus, all of which can dramatically reduce grass cover and the capacity to support livestock, especially at high densities. Invasive plants in rangelands can also be beneficial as sources of firewood, fodder, shade and medicinal products. Some species may offer considerable value when at low abundance but
\end{abstract}

T. G. O'Connor $(\bowtie)$

South African Environmental Observation Network, Pietermaritzburg, South Africa

e-mail: tim@saeon.ac.za

B. W. van Wilgen

Centre for Invasion Biology, Department of Botany and Zoology, Stellenbosch University,

Stellenbosch, South Africa

(C) The Author(s) 2020

B. W. van Wilgen et al. (eds.), Biological Invasions in South Africa, Invading

Nature - Springer Series in Invasion Ecology 14,

https://doi.org/10.1007/978-3-030-32394-3_16 
their detrimental impact far outweighs advantages as their abundance increases, resulting in a net negative value. An escalating threat of alien plants to rangelands demands innovative responses in addition to biological control and clearing programmes.

\subsection{Introduction}

Rangelands are areas of natural or semi-natural vegetation that support large mammalian herbivores. They cover $>70 \%$ of the land surface of South Africa, and include grassland, savanna, thicket, and karroid shrubland vegetation. This diversity of vegetation supports a richness of domestic and native large mammalian herbivores that consume graminoid plants, herbaceous dicotyledons, and woody plants in different proportions depending on whether they are grazers, browsers, or mixed feeders. Ecosystems dominated by woody plants therefore support more browsers, while grasslands support only grazers. Production or subsistence rangelands are used for the rearing of 40.7 million head of livestock (cattle, 12.8 million; sheep, 22.5 million; goats, 5.4 million; Department of Agriculture, Forestry and Fisheries 2018). In addition, over $60,000 \mathrm{~km}^{2}$ is set aside either as protected areas (Department of Environmental Affairs 2018a), or for farming game animals ( $\sim 3$ million head, Meissner et al. 2013).

Alien plants can provide novel foodstuffs for herbivores, but they also alter vegetation structure and composition in ways that can negatively affect herbivores. Despite their prominence, there have been few studies of the impact of alien plants on South African rangelands (Richardson and van Wilgen 2004). Impacts of invasive alien species on the ecosystem services provided by rangelands (livestock production and conservation), catchments (water supply), and biodiversity (harvested products and non-use activities) are of particular concern (van Wilgen et al. 2008).

In this chapter we assess the impact of invasive alien plants on South African rangelands. We review the types, extent, economic importance, and key ecological processes relevant to invasions of South African rangelands, and identify the status of important alien species in each biome. We address the question of whether rangeland management has influenced the success of alien plants, and consider their ecological and economic impact, illustrated by case studies. We conclude with a distillation of key features concerning the ingress of alien plants into rangelands and how effective rangeland management could be used for their control. 


\subsection{Rangelands in South Africa}

\subsubsection{Types of Rangelands in South Africa}

South African biomes serving as rangeland include parts of the Grassland, NamaKaroo, Succulent Karoo, Savanna, and Albany Thicket Biomes, and the Indian Ocean Coastal Belt, but not the Fynbos Biome (although lowland fynbos was once rangeland it has largely been transformed), Desert or Forest Biomes (Table 16.1). Dominant plant growth forms characterising each biome reflect climatic differences between the biomes (Mucina and Rutherford 2006). Grassland is dominated by perennial $\mathrm{C}_{4}$ grasses at low altitude and $\mathrm{C}_{3}$ grasses above $2700 \mathrm{~m}$ above sea level, a mixture of woody plants and perennial $\mathrm{C}_{4}$ grasses characterise the Savanna Biome, the Karoo Biomes are dominated by dwarf shrubs, especially by succulent dwarf shrubs in the Succulent Karoo Biome, with greater abundance of grasses in the eastern Nama-Karoo Biome, a mix of succulent and woody trees dominate the Albany Thicket Biome, whilst the Indian Ocean Coastal Belt Biome is a mosaic of grassland, wetland, forest and savanna.

Climate, vegetation, and historical human occupation have influenced the manner in which biomes have been used as rangeland. The San peoples who originally occupied parts of southern Africa were hunter-gatherers who did not keep domestic livestock. The first livestock in South African biomes, principally the Nama-Karoo and Succulent Karoo, arrived when the Khoekhoen immigrated into South Africa together with their herds of fat-tailed sheep (Ovis aries) about 4000 years ago (Elphick 1985). Next, Bantu peoples with their herds of cattle (Bos indicus) commenced colonising South Africa from about 1700 years ago (Huffman 2007), and Khoekhoen had also acquired cattle by 500 AD (Orton et al. 2013). The Bantu peoples occupied well-watered and wooded areas along the eastern and northern regions of the country at the time European settlement commenced during the mid-seventeenth century. Commencing in the south-west (Karoo) region, European colonists decimated wildlife by hunting and by the rapid introduction of barbed-wire fencing in the late 1800s that led to population collapses of migratory animals such as springbuck (Antidorcas marsupialis; Dean et al. 2018). Following European colonisation, a spatial pattern of land access based on race was initiated that developed into the template for land tenure and use which remains evident today. Most land was under private tenure for commercial agricultural use by white people; other ethnic groups were consolidated into blocks of land of which non-arable portions were used as communal rangeland for livestock. Currently, commercial producers use grazing systems with fenced paddocks that constrain movement of livestock (O'Reagain and Turner 1992).

Biomes differ in the type of livestock carried and the importance of wildlife. Small stock (sheep and goats) have been farmed in watered regions of the Succulent and Nama-Karoo Biomes for 4000 years, and intensely across this region over the past two centuries, ostrich farming was developed in the Little Karoo during the late nineteenth century, and springbuck farming developed from the 1960s onward (Beinart 2003). Communal land accounts for 3\% of the Succulent and Nama 


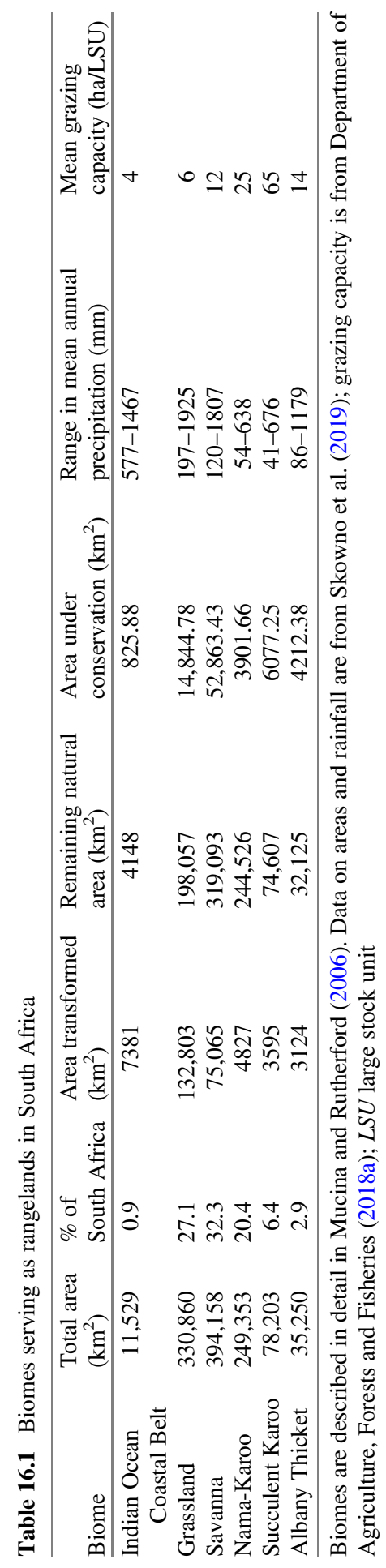


Karoo Biomes (Walker et al. 2018), on which continuous grazing by small-stock is practised (Todd and Hoffman 2009). More than 30\% of the Grassland Biome has been transformed, $<20 \%$ is under communal tenure, and the remainder is used mainly for commercial production of sheep and cattle (Mucina and Rutherford 2006). The Savanna Biome contains approximately $100,000 \mathrm{~km}^{2}$ of communal area, the backbone of state wildlife conservation areas including the Kruger National $\left(19,000 \mathrm{~km}^{2}\right)$ and Kalahari Gemsbok National $\left(9590 \mathrm{~km}^{2}\right)$ Parks, commercial ranching based mainly on cattle but including sheep and goats in semi-arid regions, and private wildlife properties that have emerged as an increasingly important land use since the 1960s (Carruthers 2008). Albany Thicket was used mainly for goat farming following European settlement but commercial wildlife enterprises are now well established. The overall value of rangeland in South Africa is reflected by the annual value of commercial livestock production estimated to be ZAR 18 billion (Meissner et al. 2013), that of the commercial wildlife industry ZAR 10 billion (Department of Environmental Affairs 2018b), and that 19 million people reside in rural areas.

Here we discuss four components of change within the rangelands described above-shifts in the composition of the herbivores, increases in the intensity of grazing, changes to fire regimes, and fencing - and their consequences for invasions (see also Box 16.1 for the evidence of the impact of grazing and fire).

\section{Box 16.1 Experimental Evidence for the Role of Fire and Grazing in Promoting or Preventing Invasion}

South Africa has a rich legacy of long-term experiments in which regimes of fire and grazing management have been manipulated in order to improve our understanding of their ecological effects. In addition, the ecological outcomes of different long-standing management regimes can commonly be compared across the fence line separating two properties. While the effects of these regimes on invasion by alien plants were not included in the formal experimental designs, the experiments or fence-line comparisons themselves offer an opportunity to examine outcomes in this regard, and to look for generalities. These experiments and contrasts have been collated in Supplementary Appendix 16.1 to provide a novel data base about the influence of management on the success of alien plants.

Exclusion of fire and grazing was investigated at eight locations ranging from semi-arid savanna through to moist grassland; investigation of fire returninterval was similarly represented along a climate gradient. Moist and mesic areas grow sufficient fuel that can support frequent fires, semi-arid systems do not. The effects of complete fire and grazing exclusion in semi-arid systems may therefore be attributed mainly to grazing exclusion; those in mesic or moist systems are usually attributed mainly to exclusion of fire. The effects of fire have not been experimentally investigated in the semi-arid Albany 
Box 16.1 (continued)

Thicket, Nama-Karoo or Succulent Karoo Biomes. Long-term exclusion of fire has promoted the success of woody alien species throughout the Grassland Biome including the Drakensberg, Athole in Mpumulanga, nThabamhlope and Ukulinga in KwaZulu-Natal, and Döhne in the Eastern Cape. All these grasslands are high rainfall or at least mesic in character. By contrast for the Savanna Biome, woody alien species were successful only in the mesic savannas of the Kruger National Park and Towoomba; woody alien species did not establish in semi-arid savannas of Kruger National Park or of Mopani, Limpopo Province. A long fire-return interval (relative to the management norm of the system) also allowed woody alien species to increase in high rainfall Drakensberg grassland and in mesic savanna in Kruger National Park. Woody alien species which gained greatest prominence when fire was excluded were Acacia mearnsii (Black Wattle) and Rubus cuneifolius (American Bramble) across the Grassland Biome, and Lantana camara (Lantana) in the Savanna Biome. Exclusion of fire also appeared to promote herbaceous alien species but this was not consistently evident.

Differences in grazing management had far less of an effect on the success of alien plant species than differences in fire management. Neither woody nor herbaceous aliens showed a response to grazing differences in mesic grassland at Athole, Kokstad, or Ermelo, in semi-arid savanna of the southern Kalahari, at the Sundays River Valley in the Albany Thicket Biome, in the Nama-Karoo Biome at Grootfontein, Carnarvon or Sundays River Valley, or in the Succulent Karoo Biome at Tierberg or Hoekdoorn. An increase in alien plants in response to heavy grazing pressure was recorded only for the Ikwezi district in the Albany Thicket Biome. The success of the shrub Atriplex lindleyi (Australian Saltbush) observed at Tierberg in the Succulent Karoo in response to grazing treatment was the result of invasion onto nutrient-enriched mounds ("heuweltjies", see Moore and Picker 1991) (Milton and Dean 2010), a response also observed following nitrogen addition. Similarly, alien herbaceous plant species are also evident in the grazing experiments in the NamaKaroo Biome at Carnarvon and Grootfontein on accumulated dung piles at livestock resting spots $(<1 \%$ of paddock area) that were absent from the rangeland matrix.

Rangelands that are managed by prescribed grazing and fire within acceptable limits therefore appear to be largely resistant to invasive alien plants.

\subsubsection{Shifts in the Composition of Herbivores}

Over large parts of South Africa, free-ranging herds of grazing and browsing wild herbivores have been replaced by domestic livestock. Domestic animals do not have the same effect as native herbivores on vegetation because there are far fewer 
livestock species than wildlife species and, consequently, less of a range in body size and feeding ecology. However, the foraging ecology of individual livestock species is similar to that of individual wildlife species. In the Karoo biomes, the feeding ecology and impact of caprines is comparable with that of the springbuck they have replaced. Within the Savanna Biome, cattle are comparable with buffalo (Syncerus caffer) in terms of body size and social aggregation, but there is no natural counterpart for cattle in the Grassland Biome. Moreover, mesic montane grasslands are stocked at 35-fold higher biomass by commercial producers than that occurring within natural wildlife ecosystems (Rowe-Rowe and Scotcher 1986).

\subsubsection{Increases in the Intensity of Grazing}

Grazing systems involving paddocks are the norm for commercial livestock production (O'Reagain and Turner 1992), with rotation among paddocks meaning that a paddock is subjected to heavy grazing then rested. Communal areas are more commonly grazed continuously but at up to three times higher stocking rates than corresponding commercial ranches (Tapson 1993; Rutherford et al. 2012b). O'Reagain and Turner (1992) concluded that stocking rate rather than grazing system was the most important management variable affecting rangeland vegetation; chronic (consistent and heavy) grazing over time has been responsible for depressed herbaceous biomass that may offer establishment opportunities for alien plants. Livestock may also create piospheres, a gradient of grazing impact diminishing with distance from water points (Thrash 1998), and nutrient-enriched patches where they repeatedly rest.

\subsubsection{The Role of Fire}

Fire is integral to the management of grassland and savanna, and is employed in grassland mainly for removing moribund material and in savanna for controlling bush encroachment (Tainton 1999). Fire-return interval across savanna and grassland is inversely related to mean annual precipitation (Archibald et al. 2009), which varies from $200 \mathrm{~mm}$ to $1200 \mathrm{~mm}$; fire-return interval correspondingly varies from $>10$ years to 1 year (van Wilgen and Scholes 1997). Woody plants establish in moist grasslands within 6 years if fire is excluded (Titshall et al. 2000). Accordingly, a biennial fire regime is commonly imposed for their control. Savanna trends toward dry thicket if fire is excluded (O'Connor et al. 2014). In semi-arid savanna or grassland, fire may occur as infrequently as once a decade, or be completely excluded if herbaceous fuel production is lessened by chronic grazing (Archibald et al. 2009). Alien plants invading grassland or savanna would therefore be expected to be fire-adapted, or to exploit fire refugia, localised areas of low fire intensity, or areas in which fire has been excluded for long enough to allow for the development 
of a stand self-protected against fire. The Karoo Biomes and Albany Thicket do not normally experience fire although a few fires have recently occurred within the transition between the Nama-Karoo and Grassland Biomes following an increase in grass biomass resulting from years of above-average rainfall (du Toit et al. 2015). Fire also interacts strongly with grazing pressure to influence vegetation responses (Box 16.1).

\subsubsection{The Influence of Fencing}

Fencing facilitates invasion of alien species through offering a perch site for birds to disperse the seeds of alien plants, as crows appear to do for Opuntia species (Dean and Milton 2000), and because fire breaks along fences are commonly prepared by breaking soil which contributes to establishment success of ruderal including alien plants (Roux 1969).

\subsection{Invasive Plants in Rangelands}

South African rangelands harbour hundreds of alien plant species, ranging from an estimated 129 species in the Nama Karoo Biome to 404 species in the Savanna Biome (van Wilgen and Wilson 2018), but $<10 \%$ of these have become seriously invasive to date (Fig. 16.1). Many alien species remain restricted to land transformed by crop agriculture, timber plantations, and urban settlements. The wetter biomes (Indian Ocean Coastal Belt, Savanna, Grassland) and riparian rather than dryland habitats within each biome have been impacted most by invasive alien plants. Wellmanaged dryland rangeland has proven to be largely resistant to invasion although a few alien species in riparian habitats have also invaded adjacent dryland; a set of species have invaded only dryland rangeland. Several invasive alien species have transformed vegetation structure owing to a larger growth form than those of native plants, especially evident for invasion by woody plants into grassland or karroid shrubland. Patches of soil disturbance or nutrient enrichment, often created by livestock, offer additional pathways of ingress into dryland rangelands. Episodic proliferation of annual grasses that may fuel fires would threaten transformation of affected areas of the Succulent Karoo Biome, whose vegetation is not adapted to fire (Rahlao et al. 2009). Many alien species establish and proliferate in response to disturbances (Hobbs and Huenneke 1992), of which grazing and fire are the two most important types in South African rangelands.

To assess biome-level patterns, we focused on species of concern identified by van Wilgen et al. (2008). We defined these as species which occupy $>10 \%$ of quarter degree grid cells of at least one biome (QDGC; $15^{\prime}$ latitude by $15^{\prime}$ longitude), species with limited distributions but severe local impacts (Rouget et al. 2004), and species which are rapidly becoming major threats to rangelands based on the extent 

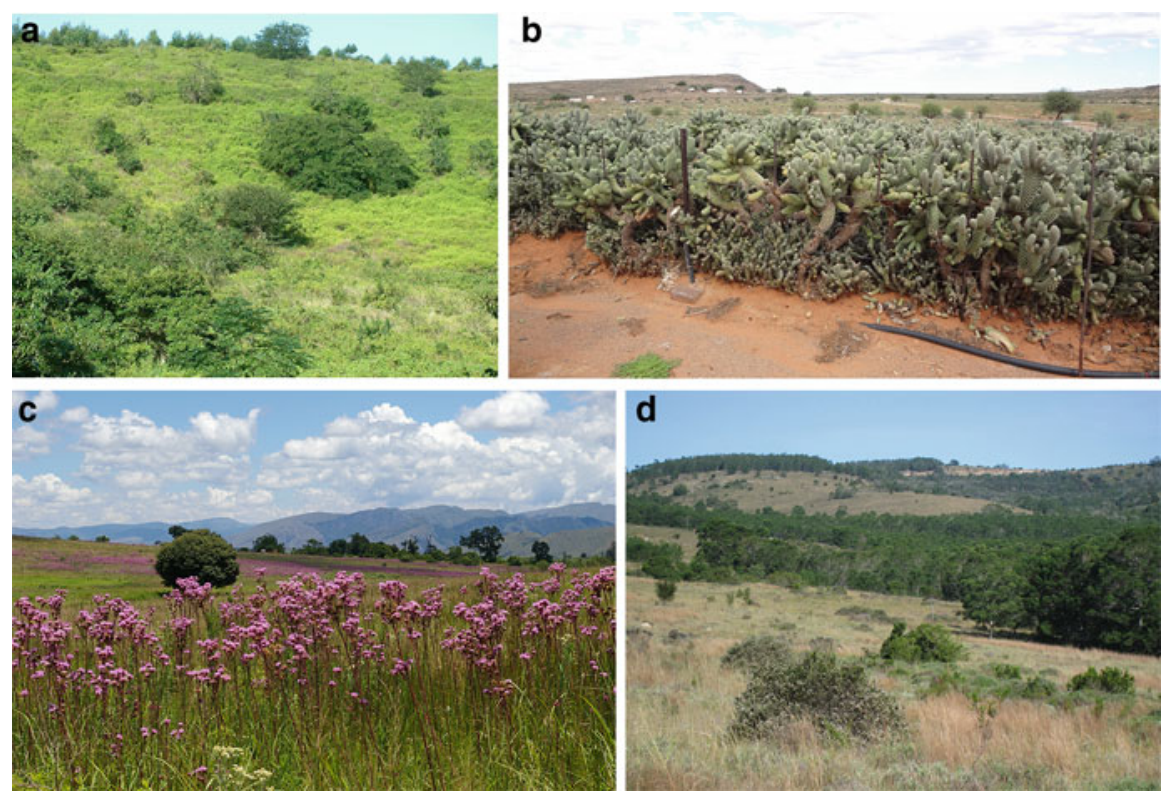

Fig. 16.1 Examples of alien plants that invade rangelands in South Africa. (a) Chromolaena odorata (Triffid Weed) in the Indian Ocean Coastal Belt in KwaZulu-Natal; (b) Cylindropuntia fulgida var. mamillata (Boxing Glove Cactus) in the Northern Cape; (c) Campuloclinium macrocephalum (Pompom Weed) in grasslands, Gauteng; and (d) Acacia mearnsii (Black Wattle) trees invading grasslands, KwaZulu-Natal. Photographs courtesy of: (a) Plant Protection Research Institute; (b) Travor Xivuri; (c) Lesley Henderson; (d) John Hoffmann

of their increase between 2000 and 2016 (Henderson and Wilson 2017). Affected biomes and habitats (riparian or dryland) were determined from the literature (e.g. Henderson 2001). We separated riparian from other habitats, as riparian areas are usually critical for large mammalian herbivores because they provide key forage resources during seasonal bottlenecks.

Of the 773 species listed in the Southern African Plant Invader Atlas data base (Henderson and Wilson 2017), 71 species were identified as being of especial importance for rangelands (i.e., are widespread, or have severe local impacts, or are rapidly increasing in extent). These included 11 tall trees, 15 medium-height trees, 1 short tree, 13 shrubs, 2 low shrubs, 5 woody climbers, 10 succulent shrubs, 1 succulent tree, 1 herbaceous climber, 3 perennial and 5 annual herbaceous species, 1 annual herbaceous shrub, and 3 perennial grasses (Table 16.2). The greatest number of important species were found within the biomes receiving higher mean annual rainfall, specifically the Grassland and Savanna Biomes and the Indian Ocean Coastal Belt, whereas the three more arid biomes (Albany Thicket, Nama-Karoo, Succulent Karoo) each contained about a half to a third of the average number of species recorded for a moist biome (Fig. 16.2). Based on a climate-envelope modelling exercise of the potential of 71 invasive species to invade further, Rouget et al. (2004) determined that the rank order (in terms of susceptibility to invasion) 


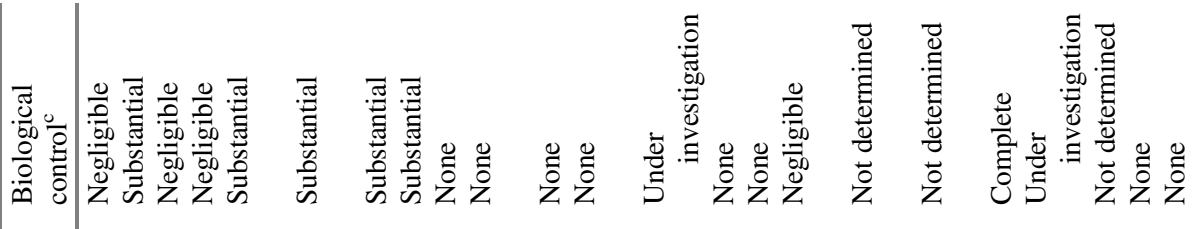
䒿

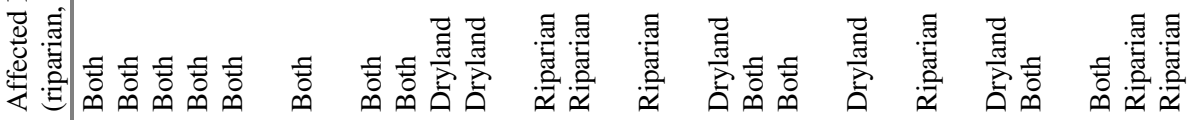

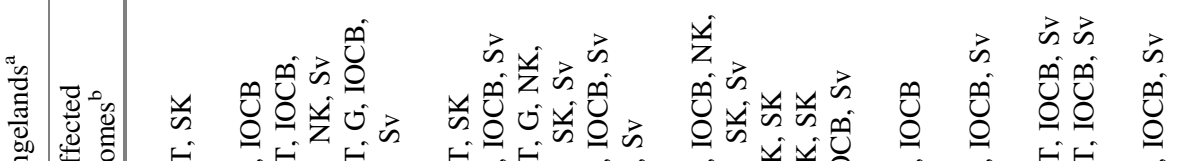

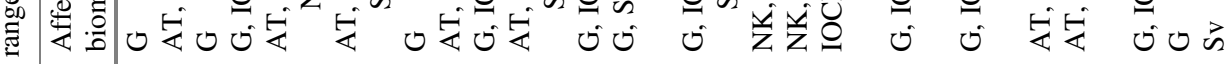

密

نे

苛

$\exists$ o

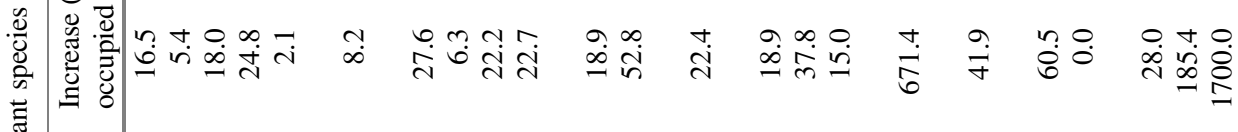

궁

:

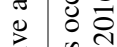

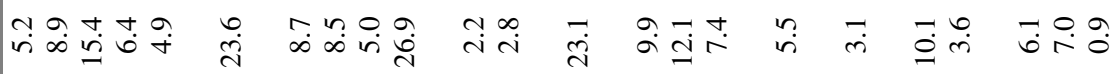

党

त

귤

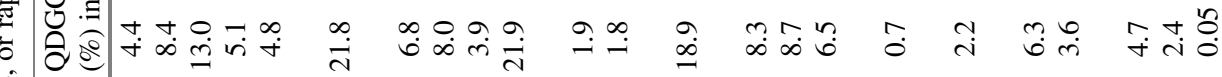

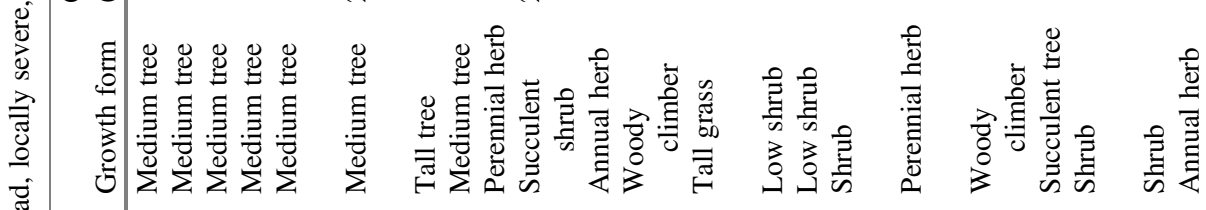

递

กู้

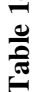

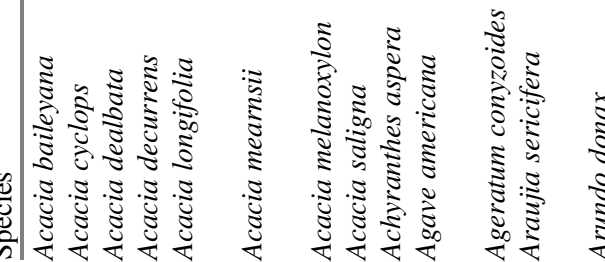

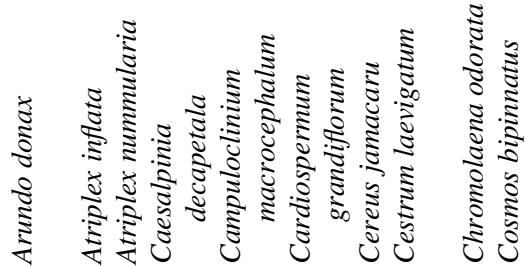




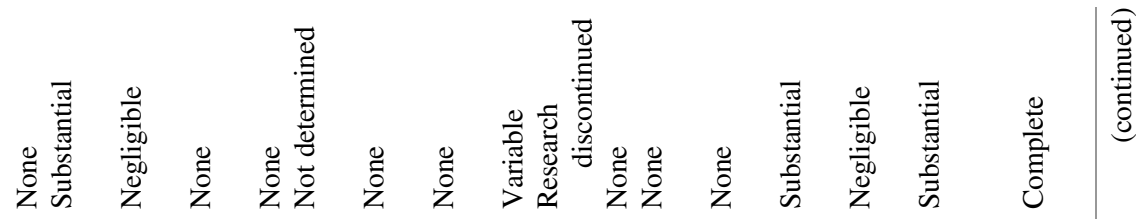

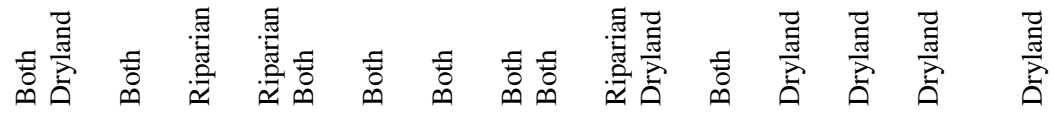

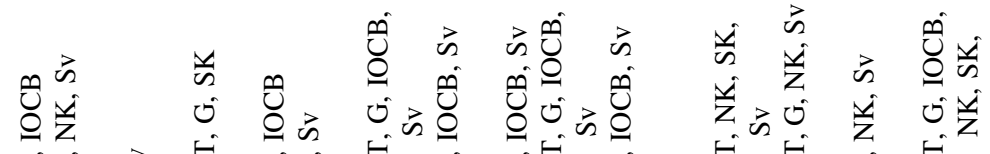

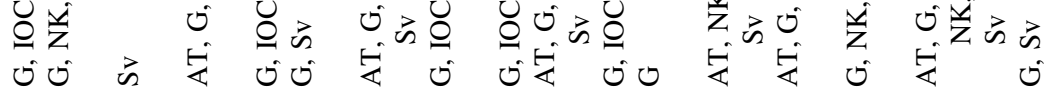

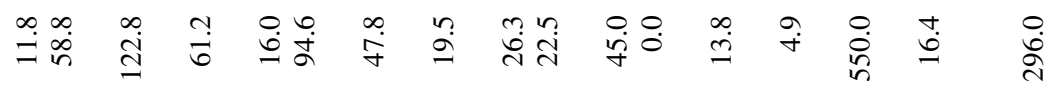

サ음

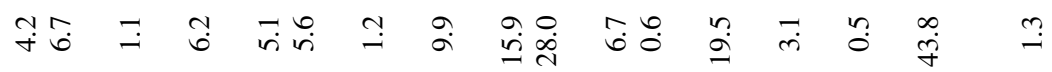

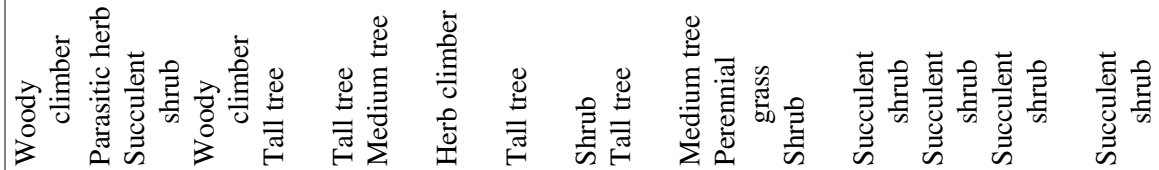

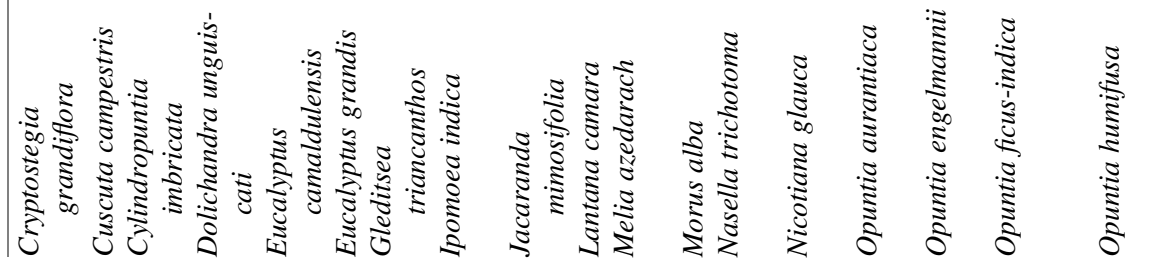




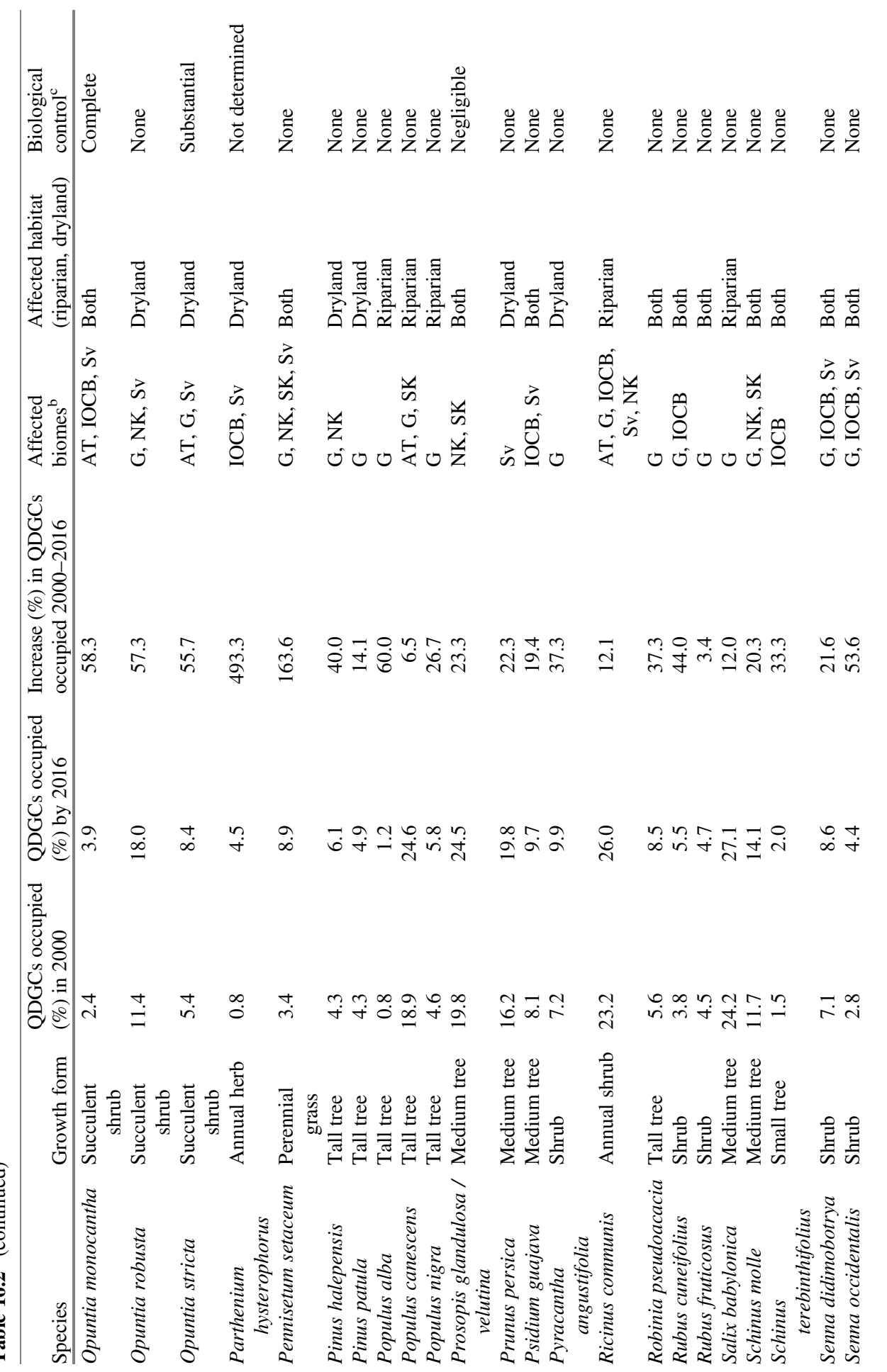




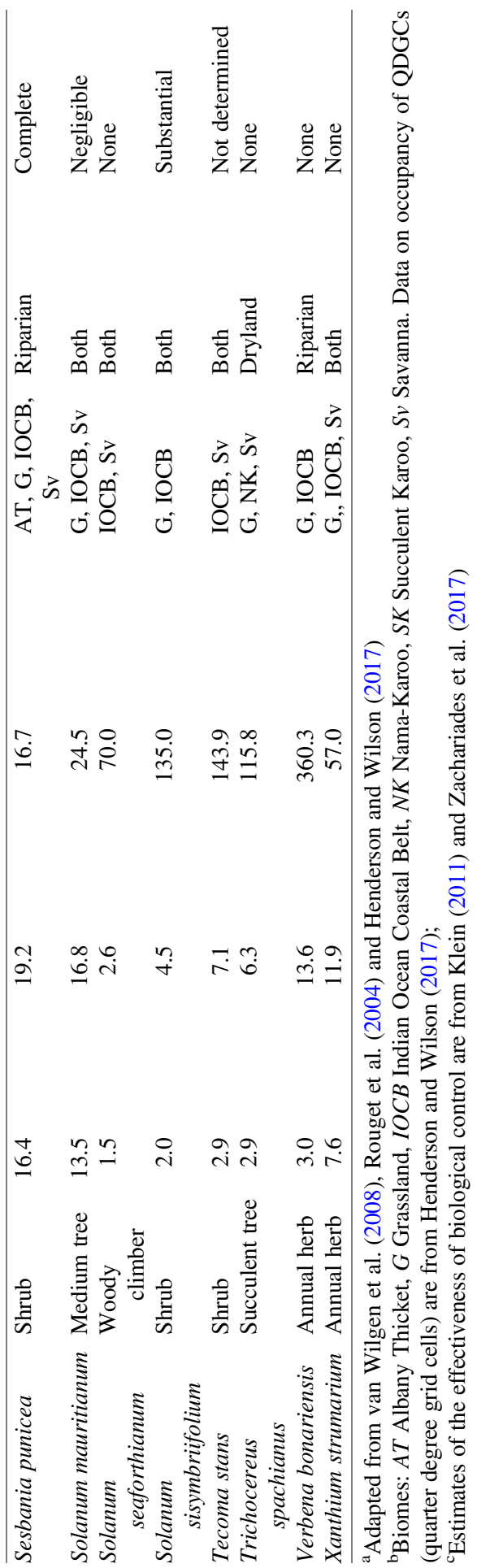



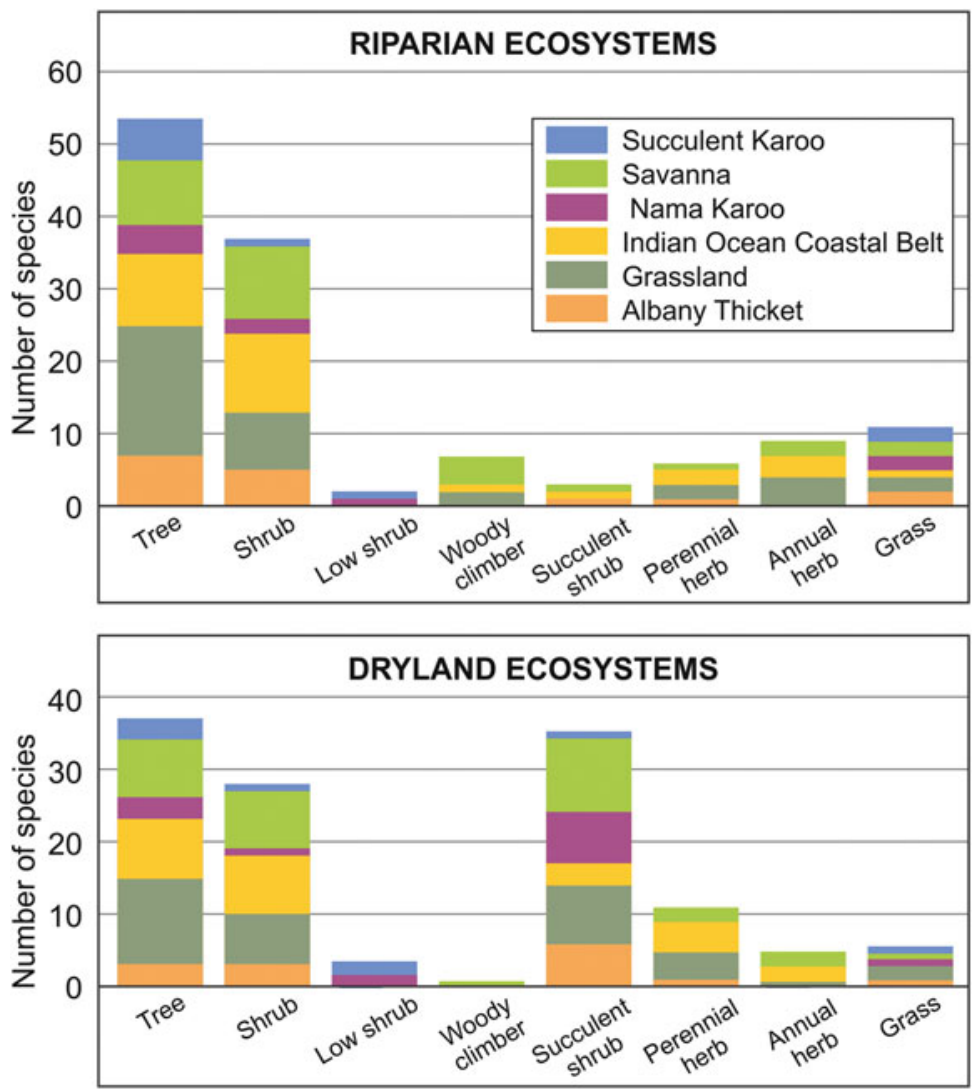

Fig. 16.2 The number of prominent alien plant species in different growth forms that impact on rangelands in six biomes in South Africa. The upper panel shows species present in riparian ecosystems, and the lower panel shows those present in dryland areas (away from riparian ecosystems). The figure is based on the 71 species listed in Table 16.2

was the Grassland Biome, Albany Thicket, Savanna Biome (including the Indian Ocean Coastal Belt), Nama-Karoo and Succulent Karoo Biomes, which described a fourfold difference in the proportion of 71 species to which a biome was vulnerable. Invasion potential of moist grassland and moist savanna vegetation types was particularly high ( $>25$ of the 71 species).

Trees and shrubs contribute the most invasive alien species in all biomes except the Nama-Karoo, in which succulent shrubs contribute the most (Fig. 16.2). Succulent shrubs were, however, also well-represented in the Grassland and Savanna Biomes. These large growth forms may therefore easily transform the host vegetation that is naturally dominated by growth forms of smaller stature, such as grasses or karroid shrubs. The tall reed Arundo donax (Giant Reed) also transforms riparian vegetation owing to its greater stature than any native riparian vegetation except 
trees. The extent or severity of transformation of native vegetation has not been well described, with a few exceptions (e.g. Prosopis spp.; van den Berg 2010; Shackleton et al. 2015), but impacts are widely evident, especially in riparian environments. Growth forms other than trees, shrubs, and succulent shrubs are not usually important invasive alien species (Table 16.2). Despite an updated national list of 256 alien grass species (Visser et al. 2017), only three grass species were prominent. However, a number of species which have more than doubled their distribution between 2000 and 2016 were herbaceous; these include Campuloclinium macrocephalum and Parthenium hysterophorus (Table 16.2; Fig. 16.1). Although many species occurred in more than one biome, a biome supports a distinctive community of alien plants, which suggests that a biome-specific approach to the control of alien plants would be appropriate (Rouget et al. 2015; see also Richardson et al. 2020, Chap. 3). Half of the important species impact both riparian and dryland habitat, whilst 19 and 16 species tend to be restricted to riparian or dryland habitat, respectively (Table 16.2). In the dry Karoo biomes, however, 65\% of the 101 alien species are found in riparian habitat (Milton and Dean 2010).

\subsection{Benefits of Alien Plants to Rangelands}

Many of the alien species that have become invasive were introduced for a specific purpose (Richardson et al. 2020, Chap. 3). For example, Milton and Dean (2010) determined that $54 \%$ of the 101 alien species recorded in arid parts of South Africa $(<250 \mathrm{~mm}$ mean annual precipitation, MAP $)$ are cultivated for utility products or services, $34 \%$ as ornamentals, and only $12 \%$ were accidental introductions. Valuable services provided by alien plants include forage and shelter for livestock, soil protection, fuel and building materials, barrier plants, medicines, and pollination. However, their relative value depends on what is displaced. A species may provide multiple services, for example Acacia dealbata (Silver Wattle) in the Eastern Cape Province is used by $100 \%$ of households for firewood, $73 \%$ for fencing, $18 \%$ as a medicine, and $79 \%$ for livestock fodder (Agripa 2016).

Alien plants may contribute to soil stability in the face of chronic grazing if they can withstand trampling and grazing, as observed for the small, mat-growing alien herb Richardia brasiliensis (Tropical Richardia), a sub-dominant plant (13\% cover) on communal grassland in the moist southern Drakensberg (O'Connor 2005). Its mat-like growth serves to intercept rainfall energy, promote infiltration, reduce lateral flow, and contain soil wash. This widespread species only becomes conspicuous in degraded swards but can be displaced by improved grazing management. By contrast, the widespread invasive alien perennial grass Pennisetum clandestinum (Kikuyu Grass) fulfils the same function but is not easily displaced once established.

Fuelwood is the primary source of energy in rural areas under communal tenure; a rural household consumes on average 5.3 tonnes of firewood annually (Shackleton 
and Shackleton 2004). Australian Acacia species are the primary source of fuel wood for many rural communities located in the Grassland Biome (Agripa 2016), in the absence of which native forest may be harvested for fuel wood (Geldenhuys and Cawe 2011). By contrast, Prosopis species are sparingly used as fuel wood, owing to most infestations being distant from settlements (van den Berg 2010), and also due to the inferior quality of mesquite wood compared with that of native species (Shackleton et al. 2015).

The medicinal plant trade in South Africa is a commercial enterprise valued at ZAR 2.9 billion annually and it involves 27 million consumers who consume 20,000 tonnes of plant material annually comprising 771 native species of which most are derived from rangeland (von Ahlefeldt et al. 2003). By contrast, only a few alien species are used for medicinal purposes. Examples include common use of Acacia dealbata in the Eastern Cape (Agripa 2016), Senna occidentalis (Stinking Weed) (Henderson 2001), and the naturalised perennial wetland herb Acorus calamus (Sweet Flag) in the Indian Ocean Coastal Belt (von Ahlefeldt et al. 2003). In most cases, rangeland lost to invasive aliens is expected to result in a loss of medicinal plants. Alien species introduced for providing edible fruits for humans include Opuntia species, Rubus cuneifolius (American Bramble), and Psidium guajava (Guava), all now very successful invaders, but all these are used incidentally as a food source. Eucalyptus species are important for supporting native bee species which pollinate most of the insect-pollinated crops in South Africa that are worth an estimated ZAR 10.3 billion annually (SANBI 2018). In extensively transformed landscapes, Eucalyptus plantations and stands serve as their primary source of food.

\subsection{Negative Impacts of Invasions on Rangelands}

\subsubsection{Physical and Economic Impacts}

This section assesses the influence of invasive alien plants on animal production through affecting the amount and quality of forage, producing harmful chemicals that may be ingested, reducing accessibility to forage, and inflicting physical harm to animals. Their effect on forage abundance depends on whether alien plants are more, equally, or less desirable for animals than the native vegetation they supplant, with the severity of this effect depending on the total area invaded. Van Wilgen et al. (2008) estimated that (at the time of their study) alien plants had caused a $1 \%$ decrease in livestock production, but predicted that this may increase to as much as $71 \%$ in the future. The forage value of a grass sward invaded by alien grasses is expected to be maintained in most instances because the majority of the 256 alien grass species in the country, of which 122 species have become naturalised and 41 species have become invasive or have had an economic impact, were introduced at pasture research stations for screening of their potential mainly as fodder plants 
(Visser et al. 2017). Examples include invasive Paspalum and Bromus species, Pennisetum clandestinum (Kikuyu Grass) and Lolium multiflorum (Ryegrass), all palatable species. By contrast, grazing capacity has been reduced by the unpalatable perennials Nasella trichotoma (Nasella Tussock) and Nasella tenuissima (White Tussock) in mountain grassland in the Eastern Cape Province, Pennisetum setaceum (Fountain Grass) in grassland and the Nama-Karoo, and by the annual Stipa capensis (Mediterranean Needle Grass), which damages wool, in the Succulent Karoo. However, even the normally unpalatable $P$. setaceum can serve as fodder during drought. We found no studies concerning the impact of alien species on wildlife systems, or which had quantified the impact of alien grasses on livestock production or on wildlife in southern Africa.

Invasion of grassland or savanna by alien trees and shrubs will markedly depress grass production as occurs with encroachment by native woody species (O'Connor and Stevens 2017). This negative impact is offset to some extent when the woody species offer palatable forage for browsers or mixed feeders. Most of the woody invasive species (legumes in the genera Acacia and Prosopis, and Chromolaena odorata, Triffid Weed) (see below) do not offer palatable foliage, although some of the legume species were introduced for their palatable pods. Cattle and browsers consume and effectively disperse the pods of, for example, Gleditsea triancanthos (Honey Locust), Leucaena leucocephala (Leucaena) and Prosopis species, and this has contributed to their recent increase in distribution (Table 16.2; 94.4\% increase for $L$. leucocephala) although these foodstuffs can be harmful when large quantities are consumed (Binggeli 2001). The foliage of all woody species listed in Table 16.2 is not considered as quality forage, although a few of these species [e.g., Acacia mearnsii, Morus alba (White Mulberry), Psidium guajava (Guava), Robinia pseudoacacia (Black Locust), Salix babylonica (Weeping Willow)] may be browsed incidentally. Schinus molle (Pepper Tree) seedlings are palatable and consequently may experience potentially high levels of mortality when exposed to sheep grazing in semi-arid savanna (Iponga et al. 2009), and this offers an approach for controlling this species which threatens to expand considerably its distribution (Rouget et al. 2004). However, even species providing poor-quality forage may be used by livestock, especially goats, under intensive stocking; examples include Acacia dealbata (Silver Wattle), Populus X canescens (Grey Poplar) (Du Toit 2016), and Lantana camara (Lantana) (T. O'Connor, pers. obs.). Atriplex species and the succulent species Agave americana (American Agave), Opuntia ficus-indica (Mission Prickly Pear) and Opuntia monocantha (Cochineal Prickly Pear) are commonly used as forage (Henderson 2001), and Melia azedarach (Syringa) has been made into silage.

Woody alien species that possess deterrents such as thorns may form impenetrable thickets that prevent access to forage, as is evident for drainage lines in the Succulent Karoo Biome, which harbours key forage resources that have been invaded by Prosopis spp. (van den Berg 2010). Dense infestations of Opuntia ficus-indica, a succulent shrub protected by thorny cladodes, had occurred in the 
Eastern Cape by the early 1900s that prevented livestock access to forage and ultimately seriously perturbed the pastoral economy of the region (van Sittert 2002). Physical damage to livestock by well-armed alien plants has been recorded in East Africa for Opuntia stricta (Australian Pest Pear) (Shackleton et al. 2017) and Prosopis spp. (Bekele et al. 2018), most commonly by thorns damaging hooves.

Animal products are the most important ecosystem service provided by rangelands. De Lange and van Wilgen (2010) estimated the economic impact of alien plant invasions on this service, using van Wilgen et al.'s (2008) estimates of livestock reduction due to invasive alien plants, and assuming a value of ZAR 2500 per large livestock unit. The estimated annual value of livestock production from rangelands in South Africa would have been ZAR 33 billion (2010 values) had they not been invaded. Current levels of invasion have reduced this by an estimated ZAR 340 million annually. These authors also attempted to estimate what the reduction would have been in the absence of historical control efforts, and concluded that current losses could have amounted to ZAR 12.7 billion had there not been historical control. However, because this estimate was based on an approach that required large assumptions, there is a low level of confidence in estimates of avoided cost (van Wilgen and Wilson 2018).

Rangelands are also critical for the provision of water services, and they provide native medicines, fuel wood, wildlife-based tourism, pollination services, and maintain the biodiversity which underpins these. Water resources provided by the higherrainfall Grassland Biome, for example, were estimated to be worth ZAR 50 billion per year under a scenario of no invasion, and this had been reduced to ZAR 48.9 billion per year due to invasions in 2010 (De Lange and van Wilgen 2010). Biodiversity can provide economic value from harvested products and non-use sources (such as tourism). The annual value of biodiversity-based services from all terrestrial biomes was estimated at ZAR 22.1 billion per year (with no invasions) and ZAR 21.7 billion per year at current levels of invasion (De Lange and van Wilgen 2010). Again, these reductions would almost certainly have been far more severe had there been no attempt at control in the past, but the magnitude of the economic value of historical control cannot be estimated with high confidence due to a lack of data.

A cost-benefit threshold is expected to apply in that alien plants may offer considerable value when at low abundance but their detrimental impact far outweighs advantages as their abundance increases (Shackleton et al. 2007; van Wilgen and Richardson 2014). For example, Prosopis trees delivered positive benefits in the form of edible pods when first introduced to South Africa, but as they spread the negative impacts grew, eventually exceeding the benefits and resulting in net negative impacts (Richardson et al. 2000; Wise et al. 2012; Fig. 16.3).

In the following paragraphs we illustrate some consequences of invasion by individual alien species on rangeland quality and condition. 


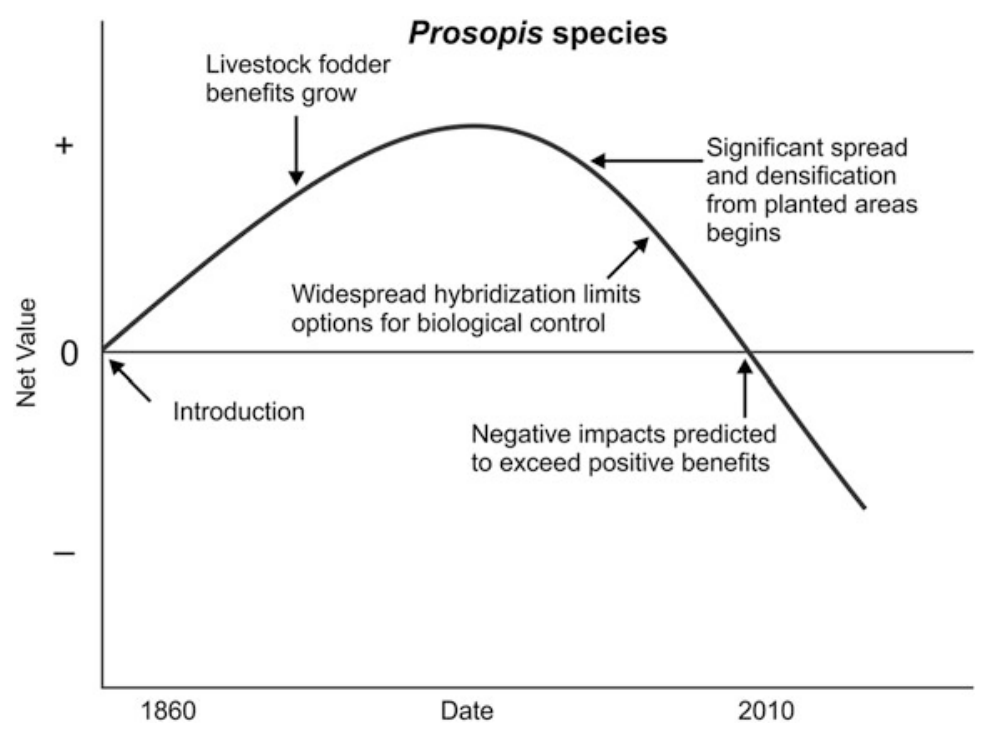

Fig. 16.3 Conceptual illustration showing changing net values (sum of benefits minus sum of impacts) over time associated with Prosopis species (economic information from Wise et al. 2012; Figure redrawn from van Wilgen and Richardson 2014)

\subsubsection{Prosopis Species (Mesquite)}

Prosopis is one of the few invasive alien taxa whose ecological and economic impacts have been reasonably well studied in South Africa (van den Berg 2010; Milton and Dean 2010; Ndhlovu et al. 2011, 2016; Shackleton et al. 2015; Zimmermann and Pasiecznik 2005; Dzikiti et al. 2018; see also Bekele et al. (2018) for information from Ethiopia). The genus Prosopis includes several tree species and their hybrids that have successfully invaded the Nama-Karoo, Succulent Karoo, and semi-arid Savanna Biomes. In the Northern Cape Province, the cover of Prosopis spp. has increased from $0.35 \%$ (127,821 ha) in 1974 to $4.06 \%$ (1.4 million ha) by 2007 (van den Berg 2010); between 2000 and 2016 the occupation country-wide of quarter degree grid cells by Prosopis glandulosa/velutina and hybrids increased by 23\% (Henderson and Wilson 2017). Mesquite trees were introduced to South Africa from the Americas to provide fodder and shade for livestock. Their pods provide fodder; foliage is not utilised by livestock.

The success of Prosopis species as invaders in South African karroid shrubland is paralleled by the encroachment of $P$. glandulosa into savanna grassland in its home range. This has been attributed to chronic grazing, resulting in low fuel loads and a consequent reduction in fire, as well as dispersal of seeds by cattle and creation of suitable micro-sites for establishment (Archer et al. 1988; Brown and Archer 1989). Although the climate and vegetation of North American $\mathrm{C}_{4}$ savanna grassland and South African karroid shrubland differ, they display a similar environmental history 
of chronic grazing and an absence of fire. In the Karoo biomes, livestock (mainly sheep) have similarly facilitated invasion of dryland through dispersal of seed from riparian areas.

In terms of impacts, Prosopis species have had a disproportionate impact on riparian areas, which serve as key resource areas for livestock during the dry season. About 30\% of riparian areas have been invaded compared with 3.3\% of dryland area (van den Berg 2010), reducing their grazing capacity (Milton and Dean 2010). For dryland rangeland, moderate levels of Prosopis invasion on a heavily grazed Nama Karoo rangeland site (approximately 15\% canopy cover) reduced grazing capacity by $34 \%$ from 3.87 to $2.56 \mathrm{LSU}$ per 100 ha (Ndhlovu et al. 2011). The negative impacts of Prosopis invasion on native vegetation (especially grasses) become apparent above a threshold of around 30\% Prosopis cover (Ndhlovu et al. 2011, 2016). Shackleton et al. (2015) found that invasion by Prosopis reduced perennial grass cover from above 15\% where the basal area of Prosopis was below $2 \mathrm{~m}^{2} / \mathrm{ha}$, to 0 where the Prosopis basal area was above $4.5 \mathrm{~m}^{2} / \mathrm{ha}$. Similarly, the cover of native perennial herbaceous plants decreased from above $20 \%$ to zero with similar increases in Prosopis cover. In contrast, the cover of annual grasses or annual herbaceous plants persisted at quite high levels of invasion.

\subsubsection{Acacia mearnsii (Black Wattle)}

Acacia mearnsii was introduced from Australia to provide tannins from bark and for wood products. This tree species has extensively invaded the relatively humid parts of South Africa, especially riparian areas, and it has occupied most of its suitable climatic envelope (Rouget et al. 2004). It showed only an $8 \%$ increase in distribution range between 2000 and 2016 (Henderson and Wilson 2017), but further increases in density are possible. Grass cover decreases in a negative exponential manner with an increase in wattle cover (Gwate et al. 2016). Yapi et al. (2018) investigated the impacts of $A$. mearnsii invasion on rangeland condition, and rangeland recovery after clearing. They found a $72 \%$ reduction in grazing capacity in densely invaded sites, and this improved by $66 \% 5$ years after clearing. In densely invaded sites, the basal cover of grasses was reduced by up to $42 \%$, resulting in a reduction in grazing capacity of $75 \%$, from 50 to 12.5 large stock units per 100 ha in uninvaded and densely invaded sites, respectively. These results suggest that, if left uncontrolled, wattle species can substantially reduce livestock carrying capacity within montane grasslands in South Africa. Exclusion of fire, by intention or as a consequence of chronic grazing that removes the grass fuels necessary for fires, promotes an increase of wattle, whereas in grasslands, this species can be controlled using repeated burning because it does not resprout. Fire-return intervals under repeated burning in mesic grasslands are usually around 2 years. Although burning stimulates germination, seedlings would not develop into a reproductive plant because the fire-return interval is too short. Acacia mearnsii possesses many traits typically associated with an aggressive invader species including prolific seed set, seeds capable of remaining 
dormant for up to 50 years, and a rapid sapling growth rate that promotes overtopping of native vegetation (Richardson and Kluge 2008).

\subsubsection{Parthenium hysterophorus (Parthenium)}

Parthenium hysterophorus is an annual herb native to tropical and subtropical America that has increased alarmingly between 2000 and 2016 (Table 16.2). It has negative impacts on livestock production, and is also a serious threat to environmental and human health because of its ability to produce chemicals that cause severe dermatitis, allergy and toxicity in humans and animals (Terblanche et al. 2016). In a study of impacts on subsistence and commercial farmers, Wise et al. (2007) found that unchecked spread reduced the economic returns to small-scale farmers by between 26 and $41 \%$, but that these losses could be offset if the levels of invasion were reduced by at least $50 \%$. However, although $80 \%$ mortality can be achieved using chemical or manual control, density of $P$. hysterophorus will return to pre-control levels within a year owing to the size of the seed bank, but density will decline if follow-up clearing is maintained (Goodall et al. 2010).

\subsubsection{Chromolaena odorata (Triffid Weed)}

Chromolaena odorata is a tall, bushy, scrambling shrub that was introduced to Africa from the Caribbean and has spread rapidly to occupy most of the climatically suitable habitats for the species in the eastern part of South Africa (Rouget et al. 2004). It has negative impacts on agricultural practices and on biodiversity. Studies of the magnitude of impacts are rare, but Wise et al. (2007) found that the introduction of a mechanical control programme saw annual returns from cattle sales increase by between 7 and $34 \%$, depending on the area of the initial invasion, in the Ntambanana district in KwaZulu-Natal, South Africa.

\subsubsection{Opuntia ficus-indica (Mission Prickly Pear)}

The invasive cactus Opuntia ficus-indica provides an example of the devastating impact that invasive cacti can have on arid rangelands. The species was responsible for severe degradation in parts of the Karoo, but has now been dramatically reduced in density over most of its distribution by effective biological control (Hill et al. 2020, Chap. 19). At the height of its dominance at the start of the twentieth century, O. ficus-indica covered almost 1 million ha of semi-arid rangelands. There were no formal ecological studies that assessed its impact at the time, but several historical overviews have recorded that these impacts were dramatic. Annecke and Moran 
(1978) noted that "Prickly pears ... are problem plants from two points of view: firstly, they form impenetrable thickets over wide areas, overwhelming the native vegetation and completely preventing normal agricultural activities: and secondly, livestock eat the fruit and cladodes, the spines and glochids of which may lead to severe or fatal gastro-intestinal disorders". Van Sittert (2002) notes that in the $1890 \mathrm{~s}$, farmers "urged the colonial state take immediate action against opuntia to save the pastoral economy from the threatened ruination of its stock holdings, labour and pastures", and that "opuntia cut deep into the material base of the settler economy and rendering it unfit for pastoral farming." Now that the species is under effective biological control, these impacts have largely been forgotten (Hill et al. 2020, Chap. 19).

\subsection{Management of Rangelands}

Rangelands are managed using manipulations of herbivory and fire that may influence the success of alien plants. Sources of information for considering these factors were studies which have contrasted the influence on botanical composition of commercial ranching, communal tenure, or conservation estate, and the results of field trials or fence-line contrasts investigating fire and grazing management.

Communal rangeland tends to support a greater diversity and abundance of alien plants than commercial rangeland in moist but not in semi-arid or arid environments. Across KwaZulu-Natal [670-1120 mm mean annual precipitation (MAP)], three alien Paspalum grass species dominated wetter communal sites but not wetter commercial or semi-arid communal sites (O'Connor et al. 2003). In the southern Drakensberg region of KwaZulu-Natal, the alien dicotyledon Richardia brasiliensis (Tropical Richardia) was a sub-dominant species on dryland communal rangeland (13\% aerial cover) but this and other alien species were almost absent from commercial or conservation grassland $(0.03 \%$ cover of $R$. brasiliensis) despite the proximity of transformed land (cultivated grass pastures, maize fields, plantations) that were dominated by a richness (50) of alien herbaceous species (O'Connor 2005). Scott-Shaw and Morris (2015) describe grazing gradients in the KwaZuluNatal midlands along which alien forb species replace native forb species lost to chronic grazing. This evidence suggests that well-managed rangeland is resistant to invasion. Wetlands were more severely invaded than drylands in this region; their total of 47 alien species included 6 of the 30 most abundant species, with wetlands in communal areas more densely invaded than those in commercial or protected areas (Walters et al. 2006). By contrast, alien species were absent or very scarce on both sides of the fence in semi-arid areas. Such fence-line contrasts included chronicallygrazed communal rangeland versus moderately-stocked commercial rangeland or nature reserves in the Succulent Karoo (Todd and Hoffman 2009), the transition from the Nama-Karoo to the Grassland Biome (Rutherford et al. 2012a), Thornveld Savanna (Rutherford and Powrie 2011), and Mopane Savanna (Rutherford et al. 2012b). Within Albany Thicket, chronic continuous grazing by domestic livestock, 
when compared to a protected area, resulted in the dominant native shrubs Euclea undulata (Common Guarri) and Portulacaria afra (Spekboom) being replaced by the native Putterlickia pyracantha (False Spike-thorn) and the invasive alien Opuntia ficus-indica (Mission Prickly Pear) (Hoffman and Cowling 1990).

Graziers commonly implement a long-term burning regime (where applicable), and a system of grazing management involving various combinations of stocking rate, animal type, and grazing intensity. The effect of these on the abundance of alien plants was assessed by compiling a novel data set of the results of long-term management experiments and long-standing fence-line contrasts of management systems (Supplementary Appendix 16.1). Box 16.1 describes the value of this database in illustrating some key management principles. First, exclusion or very infrequent fire promotes the establishment and often dominance of alien woody species in moist grassland or mesic savanna, an effect which is not apparent in regularly-burnt rangeland. By contrast, alien species are not conspicuous in semiarid savanna despite the fact that they seldom burn. Secondly, commercial dryland rangeland under prescribed grazing and fire management was largely resistant to invasive alien plants with only small amounts of a few usually herbaceous species being recorded. Alien plants increased in response to heavy grazing pressure.

Available evidence indicates that effective use of fire in particular can be used for controlling invasive plants. However, riparian habitats are vulnerable in part because they are not usually subjected to planned fires.

Biological control has been implemented for a small proportion of the 71 prominent species; specifically, 3 are considered to be completely controlled, 16 are under substantial control, 16 are under negligible control, 4 are under investigation, 5 have not been determined, and the remainder are subject to no biological control (Table 16.2) (Hill et al. 2020, Chap. 19).

\subsection{Prognosis}

The threat posed by invasive alien plants to rangelands is expected to increase with time because many species have not yet spread to occupy their potential climatic range, whereas others that have, such as Australian Acacia species, can be expected to increase in density (Rouget et al. 2004). Many currently quiescent species are expected to become invasive once an exponential phase of population growth commences (Hui and Richardson 2017). An example of this is the recent expansion of Campuloclinium macrocephalum (Pompom Weed) following a long period where it was only localised (Wilson et al. 2013). Despite increased effort to control the introduction of alien plant species into the country, the pool of alien species is growing (van Wilgen and Wilson 2018) and the irruption of new invasive species is almost inevitable.

Direct actions such as clearing and biological control will continue to provide a foundation for containing invasive alien plants, but management of rangelands and 
the animals they support have been complicit in the success of many alien species. Refinement of rangeland management in order to suppress or contain invasive alien plants deserves closer attention. Withdrawal of fire, or an increase in fire-return interval, appears to have been an important management action promoting woody alien species in the fire-dependent Grassland and Savanna Biomes. The effect of chronic grazing on the availability of fuel, especially in communal areas, has contributed to increased fire-return intervals. Appropriate resting and burning programmes should be adopted, which would further serve to suppress native bush (O'Connor et al. 2014). Fire exclusion, not uncommon with commercial producers, will lead to invasion by alien woody species into savanna and grassland. Management options in the Karoo biomes, Albany Thicket, or riparian habitats, which are not prone to fire, are limited because grazing management has less of an effect on the success of alien species, although critical study awaits. Heavy grazing intensity apparently promotes invasive alien plants. Effective seed dispersal of certain woody species by livestock can be reduced by appropriate management of their movement; palatable alien species may be contained by stocking with additional herbivore species. Rangelands, on account of covering $>70 \%$ of South Africa and influencing the delivery of the bulk of the country's ecosystem services, warrant closer investigation of the manner in which management can be refined in order to contain invasive alien plants.

The large archive of phytosociological data in South Africa awaits analysis for defining the effect of land tenure and environment on the richness and abundance of alien plants.

No panacea for preventing further increases in invasive alien plants has been unearthed. Rather, a diversity of alien species displaying a wide range in their invasion dynamics demands further innovative response to identify economically sustainable means of preventing or limiting their increase. Biocontrol has been successful in some cases, but the sheer number of invasive alien species militates against this avenue providing overall success. Achievements realised through government-sponsored clearing have been noteworthy, but this approach will require additional funding in order to maintain the current level of threat of treated species.

Acknowledgements BvW acknowledges support from the DSI-NRF Centre for Invasion Biology and the South African National Research Foundation (Grant 109467).

\section{Electronic Supplementary Material}

The online version of this chapter (https://doi.org/10.5281/zenodo.3560669) contains supplementary material, which is available to authorised users. 


\section{References}

Agripa N (2016) Perceptions and livelihood uses of an invasive alien tree (Acacia dealbata) by rural communities in the Eastern Cape. MSc thesis, Rhodes University, Grahamstown

Annecke DP, Moran VC (1978) Critical reviews of biological pest control in South Africa. 2. The prickly pear, Opuntia ficus-indica (L.) Miller. J Entomol Soc S Afr 41:161-188

Archer S, Scifres C, Bassham CR et al (1988) Autogenic succession in a subtropical savanna: conversion of grassland to thorn woodland. Ecol Monogr 58:111-127. https://doi.org/10.2307/ 1942463

Archibald SA, Roy DP, van Wilgen BW et al (2009) What limits fire? An examination of drivers of burnt area in sub-equatorial Africa. Glob Chang Biol 15:613-630. https://doi.org/10.1111/j. 1365-2486.2008.01754.x

Beinart W (2003) The rise of conservation in South Africa: settlers, livestock, and the environment 1770-1950. Oxford University Press, Oxford

Bekele K, Haji J, Legesse B et al (2018) Impacts of woody invasive alien plant species on rural livelihood: generalised propensity score evidence from Prosopis spp. invasion in Afar region in Ethiopia. Pastor Res Policy Pract 8:28. https://doi.org/10.1186/s13570-018-0124-6

Binggeli P (2001) The human dimensions of invasive woody plants. In: McNeely JA (ed) The great reshuffling - human dimensions of invasive alien species. IUCN, Gland, pp 145-159

Brown JR, Archer S (1989) Woody plant invasion of grasslands: establishment of honey mesquite (Prosopis glandulosa var. glandulosa) on sites differing in herbaceous biomass and grazing history. Oecologia 80:19-26. https://doi.org/10.1007/BF00789926

Carruthers J (2008) "Wilding the farm or farming the wild?" The evolution of scientific game ranching in South Africa from the 1960s to the present. Trans R Soc S Afr 63:160-181. https:// doi.org/10.1080/00359190809519220

De Lange WJ, van Wilgen BW (2010) An economic assessment of the contribution of biological control to the management of invasive alien plants and to the protection of ecosystem services in South Africa. Biol Invasions 12:4113-4124. https://doi.org/10.1007/s10530-010-9811-y

Dean WRJ, Milton SJ (2000) Directed dispersal of Opuntia species in the Karoo, South Africa: are crows the responsible agents? J Arid Environ 45:305-314. https://doi.org/10.1006/jare.2000. 0652

Dean WRJ, Seymour CL, Joseph GS (2018) Linear structures in the Karoo, South Africa, and their impacts on biota. Afr J Range For Sci 35:223-232. https://doi.org/10.2989/10220119.2018. 1514530

Department of Agriculture, Forestry and Fisheries (2018) Conservation of Agricultural Resources Act, Act 43 of 1983. New long-term grazing capacity map for South Africa 2017. Government Gazette No. 41870, 31 August 2018, Pretoria

Department of Environmental Affairs (2018a) EGIS protected areas database. https://egis.environ ment.gov.za/protected_areas_database

Department of Environmental Affairs (2018b) Unlocking the socio-economic potential of South Africa's biodiversity assets through sustainable use of wildlife resources. Available at: https://pmg.org.za/files/180227DEA.pdf

Du Toit JCO (2016) Control of the invasive grey poplar (Populus x canescens) using mechanical removal and grazing by livestock. Research report of the Grootfontein Agricultural Development Institute, Middelburg, pp 74-75

Du Toit JCO, van den Berg L, O'Connor TG (2015) Photographic evidence of fire-induced shifts from dwarf-shrub- to grass-dominated vegetation in Nama-Karoo. S Afr J Bot 101:148-152. https://doi.org/10.1016/j.sajb.2015.06.002

Dzikiti S, Bugan R, Le Maitre D et al (2018) Comparison of water use by Prosopis spp and the co-occurring Vachellia karroo trees before and after clearing the invasions: implications on ground water. Water Research Commission Report No 2256/1/18, Pretoria

Elphick R (1985) Khoikhoi and the founding of white South Africa. Ravan Press, Johannesburg 
Geldenhuys CJ, Cawe SG (2011) Matching resource use needs with resource status and population dynamics of target species in Transkei coastal forests to sustain resource use, Port St Johns Forest Estate, South Africa. In: Geldenhuys CJ, Ham C, Ham H (eds) Sustainable forest management in Africa: some solutions to natural forest management in Africa. Proceedings of the Sustainable Forest Management in Africa Symposium, Stellenbosch, 3-7 November 2008, Department of Forest and Wood Science, Stellenbosch University, pp 264-278

Goodall J, Braack M, de Klerk J et al (2010) Study on the early effects of several weed-control methods on Parthenium hysterophorus L. Afr J Range For Sci 27:95-99

Gwate O, Mantel SK, Finca A et al (2016) Exploring the invasion of rangelands by Acacia mearnsii (black wattle): biophysical characteristics and management implications. Afr J Range For Sci 33:265-273

Henderson L (2001) Alien invasive weeds and invasive plants. Plant Protection Research Institute Handbook No. 12, Agricultural Research Council, Department of Agriculture, Pretoria

Henderson L, Wilson JRU (2017) Changes in the composition and distribution of alien plants in South Africa: an update from the Southern African Plant Invaders Atlas. Bothalia 47(2):a2172

Hill MP, Moran VC, Hoffmann JH et al (2020) More than a century of biological control against invasive alien plants in South Africa: a synoptic view of what has been accomplished. In: van Wilgen BW, Measey J, Richardson DM et al (eds) Biological invasions in South Africa. Springer, Berlin, pp 549-568. https://doi.org/10.1007/978-3-030-32394-3_19

Hobbs RJ, Huenneke LF (1992) Disturbance, diversity, and invasion: implications for conservation. Conserv Biol 6:324-337. https://doi.org/10.1046/j.1523-1739.1992.06030324.x

Hoffman MT, Cowling RM (1990) Desertification in the Lower Sundays River Valley, South Africa. J Arid Environ 19:105-117. https://doi.org/10.1016/S0140-1963(18)30834-6

Huffman TN (2007) Handbook to the Iron Age. University of KwaZulu-Natal Press, Pietermaritzburg

Hui C, Richardson DM (2017) Invasion dynamics. Oxford University Press, Oxford. https://doi. org/10.1093/acprof:oso/9780198745334.001.0001

Iponga DM, Milton SJ, Richardson DM (2009) Soil type, microsite, and herbivory influence growth and survival of Schinus molle (Peruvian pepper tree) invading semi-arid African savanna. Biol Invasions 11:159-169. https://doi.org/10.1007/s10530-008-9221-6

Klein H (2011) A catalogue of the insects, mites and pathogens that have been used or rejected, or are under consideration, for the biological control of invasive alien plants in South Africa. Afr Entomol 19:515-549. https://doi.org/10.4001/003.019.0214

Meissner HH, Scholtz MM, Palmer AR (2013) Sustainability of the South African livestock sector towards 2050 Part I: worth and impact of the sector. S Afr J Anim Sci 43:282-297. https://doi. org/10.4314/sajas.v43i3.5

Milton SJ, Dean WRJ (2010) Plant invasions in arid areas: special problems and solutions: a South African perspective. Biol Invasions 12:3935-3948. https://doi.org/10.1007/s10530-0109820-x

Moore JM, Picker MD (1991) Heuweltjies (earth mounds) in the Clanwilliam district, Cape Province, South Africa: 4000-year-old termite nests. Oecologia 86:424-432. https://doi.org/ 10.1007/BF00317612

Mucina L, Rutherford MC (eds) (2006) The vegetation of South Africa, Lesotho and Swaziland. Strelitzia 19. South African National Biodiversity Institute, Pretoria

Ndhlovu T, Milton-Dean SJ, Esler KJ (2011) Impact of Prosopis (mesquite) invasion and clearing on the grazing capacity of semiarid Nama Karoo rangeland, South Africa. Afr J Range For Sci 28:129-137. https://doi.org/10.2989/10220119.2011.642095

Ndhlovu T, Milton SJ, Esler KJ (2016) Effect of Prosopis (mesquite) invasion and clearing on vegetation cover in semi-arid Nama Karoo rangeland, South Africa. Afr J Range For Sci 33:11-19. https://doi.org/10.2989/10220119.2015.1036460

O'Connor TG (2005) Influence of land use on plant community composition and diversity in Highland Sourveld grassland in the southern Drakensberg, South Africa. J Appl Ecol 42:975-988. https://doi.org/10.1111/j.1365-2664.2005.01065.x 
O'Connor TG, Stevens N (2017) Bush encroachment. Oxford online library. https://doi.org/10. 1093/OBO/9780199363445-0069

O'Connor TG, Morris CD, Marriott DJ (2003) Change in land use and botanical composition of KwaZulu-Natal's grasslands over the past fifty years: Acocks' sites revisited. S Afr J Bot 69:105-115. https://doi.org/10.1016/S0254-6299(15)30365-3

O'Connor TG, Puttick JR, Hoffman MT (2014) Bush encroachment in southern Africa: changes and causes. Afr J Range For Sci 31:67-88. https://doi.org/10.2989/10220119.2014.939996

O'Reagain PJ, Turner JR (1992) An evaluation of the empirical basis for grazing management recommendations for rangeland in southern Africa. J Grassl Soc South Afr 9:38-49. https://doi. org/10.1080/02566702.1992.9648297

Orton J, Mitchell P, Klein R et al (2013) An early date for cattle from Namaqualand, South Africa: implications for the origin of herding in southern Africa. Antiquity 87:108-120. https://doi.org/ 10.1017/S0003598X00048651

Rahlao SJ, Milton SJ, Esler KJ et al (2009) Effects of invasion of fire-free arid shrublands by a fire-promoting invasive alien grass (Pennisetum setaceum) in South Africa. Austral Ecol 34:920-928. https://doi.org/10.1111/j.1442-9993.2009.02000.x

Richardson DM, Kluge RL (2008) Seed banks of invasive Australian Acacia species in South Africa: role in invasiveness and options for management. Perspect Plant Ecol 10:161-177. https://doi.org/10.1016/j.ppees.2008.03.001

Richardson DM, van Wilgen BW (2004) Invasive alien plants in South Africa: how well do we understand the ecological impacts? S Afr J Sci 100:45-52

Richardson DM, Bond WJ, Dean WRJ et al (2000) Invasive alien organisms and global change: a South African perspective. In: Mooney HA, Hobbs RJ (eds) Invasive species in a changing world. Island Press, Washington, DC, pp 303-349

Richardson DM, Foxcroft LC, Latombe G et al (2020) The biogeography of South African terrestrial plant invasions. In: van Wilgen BW, Measey J, Richardson DM, Wilson JR, Zengeya TA (eds) Biological invasions in South Africa. Springer, Berlin, pp 65-94. https://doi.org/10. 1007/978-3-030-32394-3_3

Rouget M, Richardson DM, Nel JL et al (2004) Mapping the potential ranges of major plant invaders of South Africa, Lesotho and Swaziland using climatic suitability. Divers Distrib 10:475-484

Rouget M, Hui C, Renteria J et al (2015) Plant invasions as a biogeographical assay: vegetation biomes constrain the distribution of invasive alien species assemblages. S Afr J Bot 101:24-31. https://doi.org/10.1016/j.sajb.2015.04.009

Roux E (1969) Grass: a story of Frankenwald. Oxford University Press, Cape Town

Rowe-Rowe DT, Scotcher JSB (1986) Ecological carrying capacity of the Natal Drakensberg for wild ungulates. S Afr J Wildl Res 16:12-16

Rutherford MC, Powrie LW (2011) Can heavy grazing on communal land elevate plant species richness levels in the Grassland Biome of South Africa? Plant Ecol 212:1407-1418. https://doi. org/10.1007/s11258-011-9916-0

Rutherford MC, Powrie LW, Husted LB (2012a) Plant diversity consequences of a herbivoredriven biome switch from grassland to Nama-Karoo shrub steppe in South Africa. Appl Veg Sci $15: 14-25$

Rutherford MC, Powrie LW, Thompson DI (2012b) Impacts of high utilisation pressure on biodiversity components in Colophospermum mopane savanna. Afr J Range For Sci 29:1-11

SANBI (2018) Gums and bees. A roadmap for landowners in South Africa. South African National Biodiversity Institute, Pretoria

Scott-Shaw R, Morris CD (2015) Grazing depletes forb species diversity in the mesic grasslands of KwaZulu-Natal, South Africa. Afr J Range For Sci 32:21-31. https://doi.org/10.2989/ 10220119.2014 .901418

Shackleton CM, Shackleton SE (2004) The importance of non-timber forest products in rural livelihood security and as safety nets: evidence from South Africa. S Afr J Sci 100:658-664 
Shackleton CM, McGarry D, Fourie S et al (2007) Assessing the effects of invasive alien species on rural livelihoods: case examples and a framework from South Africa. Hum Ecol 35:113-127. https://doi.org/10.1007/s10745-006-9095-0

Shackleton RT, Le Maitre DC, Richardson DM et al (2015) The impact of invasive alien Prosopis species (mesquite) on native plants in different environments in South Africa. S Afr J Bot 97:25-31

Shackleton RT, Witt A, Merinyi F, van Wilgen BW (2017) Distribution and socio-ecological impacts of the invasive alien cactus Opuntia stricta in eastern Africa. Biol Invasions 19:2427-2441. https://doi.org/10.1007/s10530-017-1453-x

Skowno AL, Poole CJ, Raimondo DC et al (2019) National biodiversity assessment 2018: the status of South Africa's ecosystems and biodiversity. Synthesis report. South African National Biodiversity Institute, Pretoria

Tainton NM (1999) Veld management in South Africa. University of Natal Press, Pietermaritzburg Tapson D (1993) Biological sustainability in pastoral systems: the KwaZulu case. In: Behnke RH, Scoones I, Kerven C (eds) Range ecology at disequilibrium. Overseas Development Institute, London, pp 118-135

Terblanche C, Nänni I, Kaplan H et al (2016) An approach to the development of a national strategy for controlling invasive alien plant species: the case of Parthenium hysterophorus in South Africa. Bothalia 46(1):a2053. https://doi.org/10.4102/abc.v46i1.2053

Thrash I (1998) Impact of water provision on herbaceous vegetation in Kruger National Park, South Africa. J Arid Environ 38:315-324. https://doi.org/10.1006/jare.1997.0331

Titshall LW, O'Connor TG, Morris CD (2000) Effect of long-term exclusion of fire and herbivory on the soils and vegetation of sour grassland. Afr J Range For Sci 17:70-80. https://doi.org/10. 2989/10220110009485742

Todd SW, Hoffman MT (2009) A fence line in time demonstrates grazing-induced vegetation shifts and dynamics in the semiarid Succulent Karoo. Ecol Appl 19:1897-1908. https://doi.org/10. 1890/08-0602.1

van den Berg E (2010) Detection, quantification and monitoring Prosopis spp. in the Northern Cape Province of South Africa using remote sensing and GIS. MSc thesis, North-West University, Potchefstroom

van Sittert L (2002) 'Our irrepressible fellow-colonist': the biological invasion of prickly pear (Opuntia ficus-indica) in the Eastern Cape c.1890-c.1910. J Hist Geog 28:397-419. https://doi. org/10.1006/jhge.2001.0457

van Wilgen BW, Richardson DM (2014) Challenges and trade-offs in the management of invasive alien trees. Biol Invasions 16:721-734. https://doi.org/10.1007/s10530-013-0615-8

van Wilgen BW, Scholes RJ (1997) The vegetation and fire regimes of southern hemisphere Africa. In: van Wilgen BW, Andreae MO, Goldammer GJ et al (eds) Fire in southern African savannas: ecological and atmospheric perspectives. Wits University Press, Johannesburg, pp 27-46

van Wilgen BW, Wilson JR (2018) The status of biological invasions and their management in South Africa 2017. South African National Biodiversity Institute, Kirstenbosch and DST-NRF Centre of Excellence for Invasion Biology, Stellenbosch

van Wilgen BW, Reyers B, Le Maitre DC et al (2008) A biome-scale assessment of the impact of invasive alien plants on ecosystem services in South Africa. J Environ Manag 89:336-349. https://doi.org/10.1016/j.jenvman.2007.06.015

Visser V, Wilson JRU, Canavan K et al (2017) Grasses as invasive plants in South Africa revisited: patterns, pathways and management. Bothalia 27(2):a2169. https://doi.org/10.4102/abc.v47i2. 2169

von Ahlefeldt D, Crouch NR, Nichols G et al (2003) Medicinal plants traded on South Africa's eastern seaboard. Ethekwini Parks Department and University of KwaZulu-Natal, Porcupine Press

Walker C, Milton SJ, O'Connor T et al (2018) Drivers and trajectories of social and ecological change in the Karoo region of South Africa. Afr J Range For Sci 35:157-177. https://doi.org/10. 2989/10220119.2018.1518263 
Walters DJ, Kotze DC, O'Connor TG (2006) Impact of land use on vegetation composition, diversity, and selected soil properties of wetlands in the southern Drakensberg mountains, South Africa. Wetl Ecol Manag 14:329-348. https://doi.org/10.1007/s11273-005-4990-5

Wilson JRU, Ivey P, Manyama P et al (2013) A new national unit for invasive species detection, assessment and eradication planning. S Afr J Sci 109(5/6):\#0111, 13 p. https://doi.org/10.1590/ sajs.2013/20120111

Wise RM, van Wilgen BW, Hill MP et al (2007) The economic impact and appropriate management of selected invasive alien species on the African continent. CSIR report number: CSIR/NRE/ RBSD/ER/2007/0044/C, Council for Scientific and Industrial Research, Pretoria, $64 \mathrm{p}$

Wise RM, van Wilgen BW, Le Maitre DC (2012) Costs, benefits and management options for an invasive alien tree species: the case of mesquite in the Northern Cape. J Arid Environ 84:80-90

Yapi TS, O'Farrell PJ, Dziba LE et al (2018) Alien tree invasion into a South African montane grassland ecosystem: impact of Acacia species on rangeland condition and livestock carrying capacity. Int J Biodivers Sci 14:105-116

Zachariades C, Paterson ID, Strathie LW et al (2017) Assessing the status of biological control as a management tool for suppression of invasive alien plants in South Africa. Bothalia 47(2):a2142. https://doi.org/10.4102/abc.v47i2.2142

Zimmermann HG, Pasiecznik NM (2005) Realistic approaches to the management of Prosopis in South Africa. Forestry Research Programme R7295, UK Department for International Development, 4 p. www.hdra.org.uk/international_programme

Open Access This chapter is licensed under the terms of the Creative Commons Attribution 4.0 International License (http://creativecommons.org/licenses/by/4.0/), which permits use, sharing, adaptation, distribution and reproduction in any medium or format, as long as you give appropriate credit to the original author(s) and the source, provide a link to the Creative Commons licence and indicate if changes were made.

The images or other third party material in this chapter are included in the chapter's Creative Commons licence, unless indicated otherwise in a credit line to the material. If material is not included in the chapter's Creative Commons licence and your intended use is not permitted by statutory regulation or exceeds the permitted use, you will need to obtain permission directly from the copyright holder.

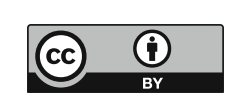

